\title{
Doctors' Visit Dilemma: Exploring The Reliability of The Data in An Outpatient Department
}

Doktora Başvuru İkilemi: Poliklinik Hastalarında Veri Güvenilirliğinin İrdelenmesi

Sabahattin AYDIN ${ }^{1}$, Olcay ÖZEN² ${ }^{2}$, Suat Hayri KÜÇÜK ${ }^{3}$, Ahmet Yaser MÜSLÜMANOĞLU ${ }^{4}$, Hanefi ÖZBEK ${ }^{5}$

\begin{abstract}
The aim of the study is to investigate the nature of outpatient-based visits to speciality care physicians in outpatient departments of a teaching hospital. A questionnaire which was in a sense "an after-visit summary" that contained patient age, gender and doctor's major office contact reason was developed. Physicians from different medical disciplines completed the questionnaire on randomly selected visits. Data was analysed statistically by descriptive analysis and cross tabulation. 1184 adult patients were analysed; 587 [49.6 (\%)] of them were visited by medicine specialists, and 597 [50.4 (\%)] by surgeons. Among all adult admissions, first patients comprised less than half of the workload, $40.8(\%)$ in surgery and $43.5(\%)$ in medicine. There was a significant difference between the number of patient contacts in medical and surgical specialities in terms of major visit categories. Compared to first visit, numbers of established patients, office consultation and reporting were significantly higher, whereas number of prehospitalizations was significantly lower in medicine than surgery. As shown in the study, per capita doctors' visit data is not very reliable, nor is it uniform in OECD database, disabling the comparison between countries.
\end{abstract}

Keywords: Doctor-patient relationship, Health care utilization, Patients, Patient actions

\section{ÖZET}

$\mathrm{Bu}$ çalışmanın amacı, bir eğitim araştırma hastanesinin farklı polikliniklerine başvuran ayaktan hastaların başvuru nedenlerini incelemektir. Araştırmamızda farklı polikliniklerden hekimler tarafından doldurulan, hastanın yaşı, cinsiyeti ve başvuru nedenini içeren; bir bakıma "muayene sonrası özeti" olan bir çizelge geliştirilmiştir. Hekimler çizelgeyi rastgele seçilen muayeneler arasından tamamlamışlardır. Elde edilen verilerden çapraz tablolar oluşturulmuş ve tanımlayıcı istatistik ile analiz edilmiştir. 1184 yetişkin hasta analiz edilmiş olup; 587'si $(\% 49,6)$ dahili klinikleri, 597'si $(\% 50,4)$ cerrahi klinikleri hekimlerince muayene edilmiştir. Tüm yetişkin başvuruları arasındaki hastaların yarısından azı hem dahili [40,84 (\%)] hem de cerrahi [43,55 (\%)] polikliniklerde ilk kez hekime başvuru yapan hastalardır. Dahili ve cerrahi polikliniklere yapılan hasta başvuru nedenleri arasında önemli bir farklılık bulunmaktadır. İlk muayeneleri kıyasladığımızda dahili branşlarda, takipli hasta sayısı, konsültasyon ve rapor yazdırma sayıları cerrahi branşlara göre önemli ölçüde daha yüksekken, hastaneye yatış öncesi yapılan muayene sayısı cerrahi branşlara göre önemli ölçüde daha düşük çıkmıştır. Çalışmada gösterildiği gibi, doktor başına düşen muayene verileri güvenilir olmamakla birlikte OECD veri tabanında bu konuda tam bir tanım birliği bulunmamaktałır, bu da ülkeler arasındaki karşılaştırma yapılmasını engellemektedir.

Anahtar Kelimeler: Doktor-hasta ilişkisi, Hastalar, Hasta davranışları, Sağlık hizmetinden yararlanma

\footnotetext{
1 Prof. Dr., Sabahattin AYDIN, Sağlık Yönetimi, İstanbul Medipol Üniversitesi Sağlık Sistemleri ve Politikaları Araștırma Merkezi, saydin@medipol.edu.tr, ORCID: 0000-0001-6374-817X

${ }^{2}$ Dr., Olcay ÖZEN, Sağlık Yönetimi, İstanbul Medipol Üniversitesi Sağlık Sistemleri ve Politikaları Araştırma Merkezi, oozen@medipol.edu.tr, ORCID: 0000-0001-6562-8286

${ }^{3}$ Dr., Suat Hayri KÜÇÜK, Klinik Biyokimya, Sağlık Bilimleri Üniversitesi Bağcılar Eğitim ve Araştırma Hastanesi, suatkucuk@gmail.com, ORCID:0000 0003 0267-1302

4 Prof. Dr., Ahmet Yaser MÜSLÜMANOĞLU, Üroloji, Sağlık Bilimleri Üniversitesi Bağcılar Eğitim ve Araştırma Hastanesi, ymuslumanoglu56@hotmail.com, ORCID: 0000000286910886

${ }_{5}$ Prof. Dr., Hanefi ÖZBEK, Farmakoloji, İzmir Bakırçay Üniversitesi, hanefi.ozbek@bakircay.edu.tr, ORCID: 0000-0002-8084-7855
} 


\section{INTRODUCTION}

Health care utilization depends on many factors that relate to both health care system and characteristics of individual patients. However, the critical issue is the interaction of people and the health care system. For an efficient health care system, it is necessary to acquire an in-depth understanding of the characteristics, healthcare use and other factors that influence the outcomes.

There are many indicators that reflect the system performance. The OECD Health Database presents the most extensive source of comparable statistics on health and health systems across OECD countries. It is a crucial tool to conduct comparative analyses and draw lessons from international comparisons of diverse health systems. Among these data, health care utilization is the key issue to show the interaction of the people and health system. ${ }^{1}$ Several indicators are used to measure health care utilization in a country, among which average instances of visits/consultations with a physician per individual per annum is the most prominent one. However, international comparison of this variable shows great diversity, a situation difficult to explain.

Recently available yearly per capita doctors' visit of the countries are seen in Figure 1. As the figure demonstrates, per capita doctors' visit in Turkey is above the OECD average. ${ }^{2,3}$

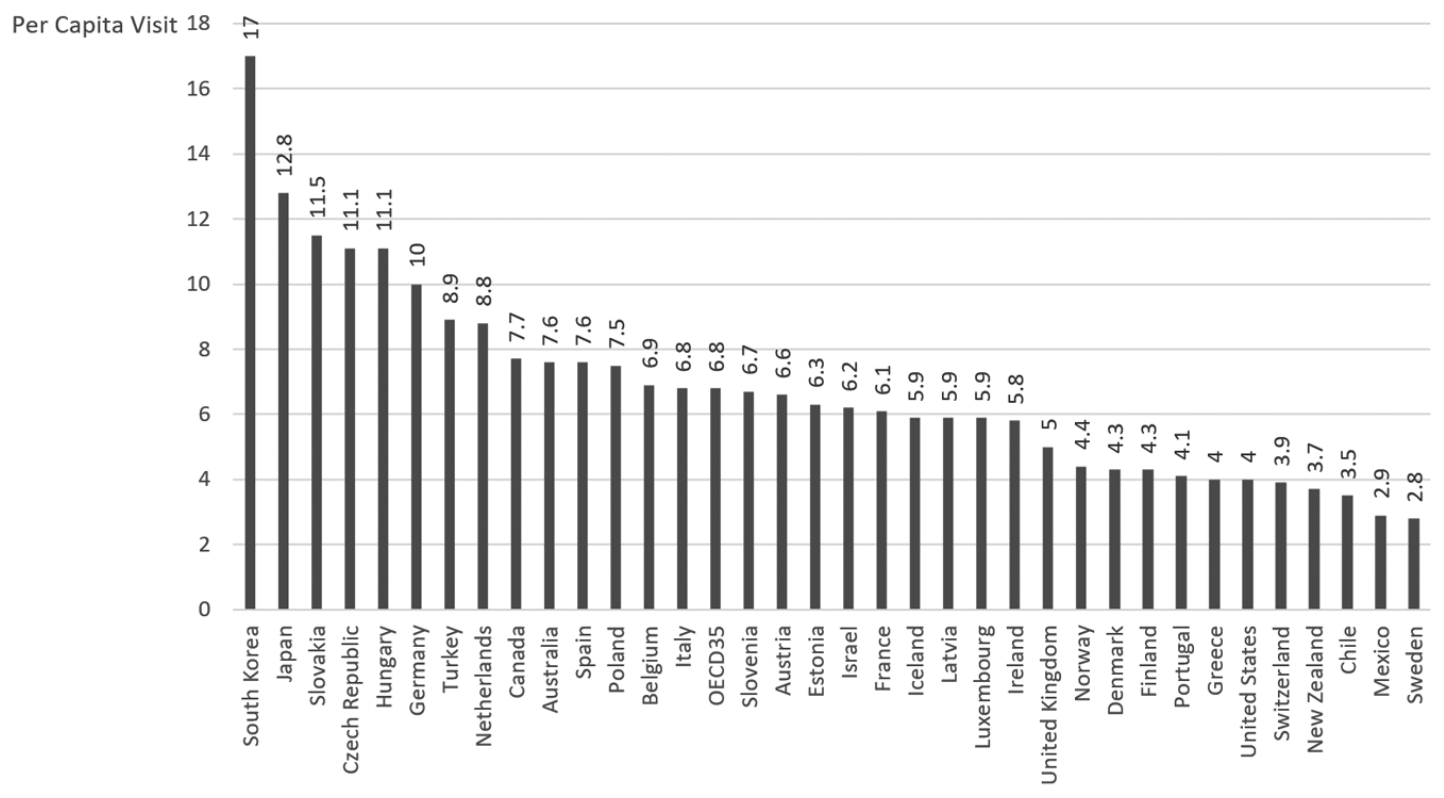

Note: Turkey's data belongs to the year 2017. Countries' data belong to the year of 2016 or nearest.

Figure 1. International Comparison of Per Capita Visits to a Physician, $2016{ }^{3}$

The countries which have more per capita visit than Turkey are Germany (10), Hungary and Czech Republic (11.1), Slovakia (11.5), Japan (12.8) and South Korea (17). On the other hand, the lowest numbers of per capita doctors' visit belong to the countries such as Sweden (2.8), Mexico (2.9), Chile (3.5) and New Zealand (3.7). It is not possible to explain the similar figures between countries which have extremely different socioeconomic dynamics and health status such as
Sweden and Mexico. Likewise, it is not easy to explain the great difference between some countries; for instance, while per capita visit in New Zealand is 3.7, it is 17.0 in South Korea. It is also unlikely to explain the difference between Sweden and South Korea by considering their patient loads, sociocultural structures and even access to health services. 
OECD data does not differentiate consultation from actual visit. Generally, doctor's office, in the patient's residence, in outpatient clinics in hospital and itinerant health care centers are all included. Telephone and email contacts, visits for prescribed laboratory tests or to perform prescribed and scheduled treatment procedures were excluded if possible. ${ }^{4} \mathrm{We}$ are not sure if all the countries were able to fulfill these criteria, since various methodologies were reported to obtain the data.

Indeed, variability of definitions, the sources of data and the methods to obtain the data seem to be the main reasons of this inconsistency. Thus, it is not easy to make a reliable comparison between countries nor is it satisfactory to estimate it clearly even within the same country. It is debatable whether health policy makers agree on whether a clear definition and reliable qualified data is obtained.

The case is also same for Turkey. It is clear that people have started to have an easier consultations and visits both to generalist and specialist medical practitioners, whether at the access to health services in recent years in Turkey. In the early 2000 s, per capita doctors' visit was only 3 , while it has been reported that this number has reached to 8.9 today. The most comprehensive research on per capita visits in the past is "The Utilization of Health Services" from June, 1992. It was conducted by Ministry of Health, Health Projects Department. ${ }^{5}$ This research aimed to find out the characteristics of people who had health services. Also, it aimed to reveal the factors affecting the utilization of health services. In this research, the average per capita doctors' visit was reported to be 2.44 per year.

According to the statistical yearbooks of Ministry of Health, per capita doctors' visits was 3.1 in 2002. In the years after, the figure increased consistently and became 8.2 in 2011 and remained steady until 2013. The latest statistics of the Ministry show that the number has reached to $8.9 .^{3}$

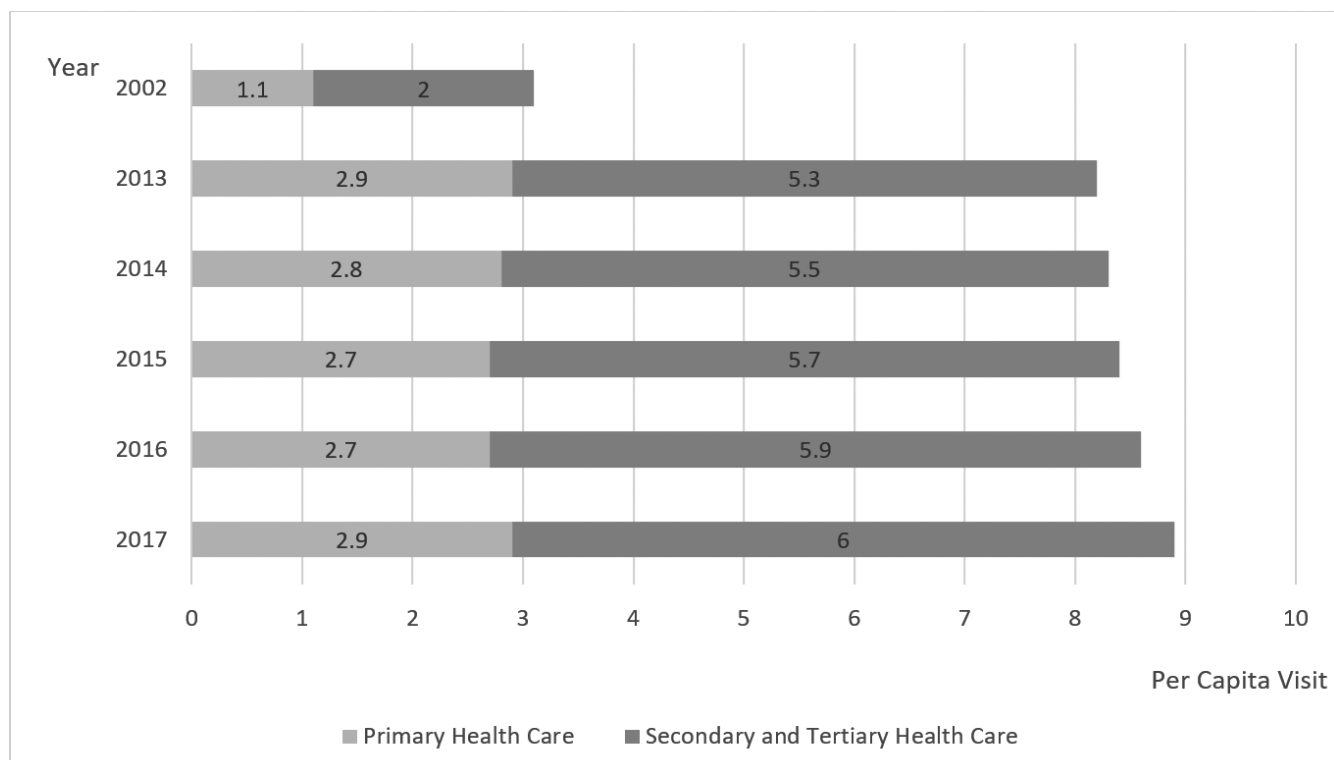

Figure 2. Total Number of Per Capita Visits to a Physician in Health Care Facilities by Years, All Sectors ${ }^{3}$

The previous estimations about doctors' visits had some limitations. The health coverage was limited. Patients used other ways to see doctors for health services outside the hospitals even if they had social insurance. Patient records in health institutions were manual; patient visits were estimated by analysing clinical patient record books or by household surveys.

Unlike the past, today, Turkey has a successful universal health coverage. Almost 
all data about health services received within the coverage are sent digitally to Social Security Institution (SSI) by public and private health institutions. Ministry of Health collects data from all health institutions by systems such as Sağlık-Net and e-Nabız. However, the quality of the data is still questioned.

As seen in Figure 2, doctor's visits are grouped as per capita visits to primary health care facilities and to speciality care visits named as secondary and tertiary care health facilities, including hospitals of Ministry of Health, teaching hospitals, speciality branch centers, private hospitals and outpatient clinics.

Per capita admission to primary healthcare has been steady since 2013. The increasing part is the admission to specialists which constitutes secondary and tertiary care. With regard to this, the study aimed to analyse the nature of the admissions to specialists in a hospital setting.

\section{MATERIALS AND METHODS}

The study was conducted in one of the biggest public hospitals in Istanbul. The workload of the outpatient department of the hospital was monitored during one-month period (October 2018). Ward visits, consultations during inpatient stay or day care treatment and admissions to the emergency department were excluded.

35 physicians completed the questionnaire on randomly selected visits, which was in a sense "an after-visit summary" that contained patient age, gender and doctor's major office contact reason. Data collected in outpatient pediatric department and data for adult patients, derived from internal medicine and surgical specialities were evaluated separately. Non-procedure-based specialties such as internal medicine, dermatology, endocrinology, nephrology, physical therapy and rehabilitation, gastroenterology, cardiology, neurology and psychiatry were grouped under medical specialities, shortly named as "medicine". Procedure-based specialities such as general surgery, anesthesiology, neurosurgery, urology, ENT, ophthalmology, obstetrics and gynecology were grouped under surgical specialities and named as "surgery".

Major reasons for outpatient-based visits to speciality care physicians were grouped under 13 categories.

1-New patient: The visit is considered to be of a new patient who has not been seen before by the physician, or by any other physician of the same speciality in the same hospital. This visit requires the most comprehensive medical history and physical examination of the patient.

2-Established patient: The visit is considered to be of an established patient whose medical history and the established diagnosis has already been present in the patient's records and thus familiar to the physician. In other words, it is a follow-up visit that requires examination of the patient in connection with the diagnosis recorded in the patient's file.

3-Treatment control: inviting the patient to the outpatient clinic to see the progress of the of the patient recently placed on a new medication.

4- Office consultation: consultation is the service rendered by the physician whose opinion or advice regarding a specific problem or condition is sought by another physician.

5- Transfer of care: referring the patient to another physician from different speciality to take over the responsibility for managing the patient's care or follow-up.

6- Advice: evaluating the patient's complaints and making advice or guidance without physical examination or just giving information about the patient's problems

7- Selected services: visiting for prescribed laboratory tests or imaging without further examining the patient. 
8- Prescription: writing drugs due to complaint or request of the patient as well as rewriting the drugs that were written or used before, without need for examination.

9- Pre-hospitalization: admission to the outpatient department before hospitalization (there may be reasons such as pereop, examination, appointment etc.)

10- Request for referral: referring the patient due to his or her request or referring because of reimbursement procedures.

11- Reporting: preparing a report to document the condition of the patient for various reasons (prescription, military, marriage, disability, sports, travel, employment etc.,)

12- Social indication: applying just to escape from work, house, or any other environment without being a real patient.

13- Other reason: admission to the outpatient clinic with a reason other than those mentioned above
Statistical analyses were performed using the SPSS software version 18. Due to big difference, pediatric patients were not included in statistical analyses. The variables were investigated using Shapiro-Wilk's test to determine whether they are normally distributed. Descriptive analyses were presented using means and standard deviations (SD). Since the age values were not normally distributed; Mann-Whitney U test was used to compare the gender and visit groups. One-way ANOVA test was used to compare the categories of visits (post-hoc Tamhane-T2 test). The proportions of patients were presented by gender and visit groups using cross tabulations. The Chi-square test (Pearson Chi-Square, Continuity correction, Fisher's exact, Monte Carlo) was used to compare these proportions in different groups. A p-value of less than 0.05 was considered to show a statistically significant result.

\section{RESULTS AND DISCUSSION}

The total number of non-emergency visits during the reporting month was 157.458 in the outpatient clinic and were realized by 228 physicians from different specialities. According to the hospital records 126,304 of these visits $(80.21(\%))$ were new patient admissions, whereas 31,154 of them (19.79 (\%)) were scheduled controls. About 30 patients per doctor were examined daily.

Data for 1.404 patients $\{570$ were males [40.6 (\%)] and 834 females [59.4 (\%)]\} were collected during the reporting period. Ages ranged between 1 month and 90 years old.

1184 adult patients were investigated in our study, of which 587 [ (49.6 (\%)] were visited by medicine specialists, and 597[50.4 (\%)] by surgeons. 229 [(48.4 (\%)] of those visited by medicine physicians were males and 358 [50.4 (\%)] were females. On the other hand, 244 [51.6 (\%)] of those visited by surgeons were males and 353 [49.6 (\%)] were females. There was no significant difference between genders in terms of admission to different medical disciplines $(\mathrm{p}=0.514)$.

The mean age of male patients was $45.78 \pm$ 20.70 and the mean age of females was 43.37 \pm 18.68 , with no statistical difference $(p=0,181)$. However, the mean age of patients that were seen in internal medicine departments $(50.04 \pm 17.95)$ was significantly higher than that of patients in surgical departments $(39.81 \pm 19.71)(\mathrm{p}=0.000)$. Age and gender distribution of adult patients can be seen in Table 1 . 
Table 1. Age And Gender Distribution of Adult Patients According to Their Major Visit Categories

\begin{tabular}{|c|c|c|c|c|c|c|c|c|}
\hline \multirow[b]{3}{*}{ Category } & \multirow{3}{*}{$\begin{array}{c}\text { Age } \\
(\text { mean } \pm \text { SD })\end{array}$} & \multicolumn{4}{|c|}{ Gender } & \multirow{2}{*}{\multicolumn{3}{|c|}{ Total }} \\
\hline & & \multicolumn{2}{|c|}{ Male } & \multicolumn{2}{|c|}{ Female } & & & \\
\hline & & $\mathbf{N}$ & $(\%)$ & $\mathbf{N}$ & $(\%)$ & $\mathbf{N}$ & \multicolumn{2}{|c|}{$(\%)$} \\
\hline 1 & $43.05 \pm 18.86$ & 182 & 38.5 & 314 & 44.2 & & 496 & 41.9 \\
\hline 2 & $47.828 \pm 18.26^{*}$ & 101 & 21.4 & 156 & 21.9 & & 257 & 21.7 \\
\hline 3 & $45.37 \pm 19.99$ & 46 & 9.7 & 84 & 11.8 & & 130 & 11.0 \\
\hline 4 & $51.75 \pm 22.47$ & 16 & 3.4 & 16 & 2.3 & & 32 & 2.7 \\
\hline 5 & $52.57 \pm 12.74$ & 2 & 0.4 & 5 & 0.7 & & 7 & 0.6 \\
\hline 6 & $40.47 \pm 25.09$ & 8 & 1.7 & 7 & 1.0 & & 15 & 1.3 \\
\hline 7 & $41.00 \pm 16.81$ & 20 & 4.2 & 30 & 4.2 & & 50 & 4.2 \\
\hline 8 & $51.25 \pm 18.21$ & 20 & 4.2 & 32 & 4.5 & & 52 & 4.4 \\
\hline 9 & $41.12 \pm 20.95$ & 48 & 10.1 & $43 * *$ & 6.0 & & 91 & 7.7 \\
\hline 10 & - & 0 & 0.0 & 1 & 0.1 & & 1 & 0.1 \\
\hline 11 & $45.10 \pm 23.95$ & $26^{* *}$ & 5.5 & 16 & 2.3 & & 42 & 3.5 \\
\hline 12 & $75.00 \pm 15.56$ & 1 & 0.2 & 1 & 0.1 & & 2 & 0.2 \\
\hline 13 & $52.44 \pm 25.94$ & 3 & 0.6 & 6 & 0.8 & & 9 & 0.8 \\
\hline Total & $44.93 \pm 19.52$ & 473 & 100.00 & 711 & 100.00 & & 1184 & 100.00 \\
\hline
\end{tabular}

Established patients (category 2) were significantly older than the new patients. as expected $(\mathrm{p}<0.05)$. There was a significant difference between the number of males and females in terms of major visit categories ( $p$ $=0.030$ ). Females were significantly higher in pre-hospitalization group (category 9) but males were significantly higher in reporting group (category 11) compared to new patients.

The number of patients that comprised the study in pediatric. medical and surgical outpatient departments and their major reasons for visiting are given in Table 2 .

Table 2. The Distribution of The Pediatric And Adult Patients According to Their Major Visit Categories

\begin{tabular}{|c|c|c|c|c|c|c|c|c|c|}
\hline & \multicolumn{3}{|c|}{ Pediatry } & \multicolumn{4}{|c|}{ Adult } & \multicolumn{2}{|c|}{ Total } \\
\hline & & & & Medicine & & Surgery & & & \\
\hline Category & $\mathbf{N}$ & & $(\%)$ & $\mathbf{N}$ & $(\%)$ & $\mathbf{N}$ & $(\%)$ & $\mathbf{N}$ & $(\%)$ \\
\hline 1 & & 121 & 55 & 236 & 40.2 & 260 & 43.6 & 617 & 43.9 \\
\hline 2 & & 22 & 10 & $164 *$ & 27.9 & 93 & 15.6 & 279 & 19.9 \\
\hline 3 & & 21 & 9.6 & 61 & 10.4 & 69 & 11.6 & 151 & 10.8 \\
\hline 4 & & 9 & 4.1 & $22 *$ & 3.7 & 10 & 1.7 & 41 & 2.9 \\
\hline 5 & & 9 & 4.1 & 4 & 0.7 & 3 & 0.5 & 16 & 1.1 \\
\hline 6 & & 8 & 3.6 & 6 & 1.0 & 9 & 1.5 & 23 & 1.6 \\
\hline 7 & & 14 & 6.4 & 23 & 3.9 & 27 & 4.5 & 64 & 4.6 \\
\hline 8 & & 6 & 2.7 & 31 & 5.3 & 21 & 3.5 & 58 & 4.1 \\
\hline 9 & & 1 & 0.5 & 5 & 0.9 & $86^{*}$ & 14.4 & 92 & 6.6 \\
\hline 10 & & 4 & 1.8 & 0 & 0.0 & 1 & 0.2 & 5 & 0.4 \\
\hline 11 & & 5 & 2.3 & $30 *$ & 5.1 & 12 & 2 & 47 & 3.3 \\
\hline 12 & & 0 & 0 & 1 & 0.2 & 1 & 0.2 & 2 & 0.1 \\
\hline 13 & & 0 & 0 & 4 & 0.7 & 5 & 0.8 & 9 & 0.6 \\
\hline Total & & 202 & 100 & 587 & 100 & 597 & 100 & 1404 & 100 \\
\hline
\end{tabular}

A notable discrepancy was present considering the instances of "medicine" and "surgery" within the context of major visit categories $(p=0.000)$. Compared to first visit. numbers of established patients (category 2). office consultation (category 4) and reporting (category 11) were significantly higher. whereas number of pre-hospitalization 
(category 9) was significantly lower in medicine than surgery.

In the pediatrics group. the majority [55(\%)] seemed to be new patients. However. less than half of the patients in adult groups were first patients. both in medicine and surgery [40.84 (\%) vs $43.55(\%)]$. In other words. the majority of the adults who admitted to the outpatient department had already been visited before for some reason.

The rate of established patients whose medical history and established diagnosis has already been present in the patient's records was $19.9(\%)$. It was quite low in pediatric group $10(\%)$ but was as high as $27.9(\%)$ in adults in medicine.

Treatment control. in other words. the follow-up of the patients was also done in the same department by the same physicians with a rate between $9.6(\%)$ and $11.56(\%)$.

$4.2(\%)$ of the patients made the specialists busy for selected services such as prescribed laboratory tests or imaging without need for further examination. In addition. 4.1 (\%) of the patients admitted to the department only for request for prescription. This rate is quite high in medicine [5.3 (\%)]. However. prehospitalization visit rate in surgery was significantly higher $[14.4(\%)]$ than in medicine.

Statistically significant number of adult patients in medicine [5.1 (\%)] had contacts with the physicians not for health care service. but request for a report for documenting the condition of the patients for various reasons.

Interestingly. only limited number of patients were sent for consultation. the highest rate being significantly in pediatric group [4.1 $(\%)$ ]. Request for referral and visiting for social indication were unexpectedly rare.

The common definition of a doctor's visit is a meeting between a patient with a physician to get health advice or treatment for a symptom or condition. Sometimes consultation is used as a synonym. However. generally the term consultation does not refer to a simple visit. It is the service provided by a physician whose opinion or advice regarding evaluation of a specific problem is requested by another physician.

OECD data does not make any distinction between these words. On the other hand. country data differs according to the conception of the term by each country. For instance. the data from Turkey is reported to comprise individual visits to primary. secondary and tertiary care health facilities. ${ }^{6}$ Nothing is mentioned about consultation.

In Turkish health system. primary care is given in family health centers mainly by family medicine specialists or general practitioners. Secondary and tertiary care is delivered by those who specialize in particular areas of medicine. Specialist care is free through the public health system in public hospitals and contracted private hospitals. Thus. the doctor's visit data implies just physician-doctor contacts in doctors' clinics and outpatient departments. No data is available about the nature of the contact. Discounting treatment control visits proves to be futile. along with prescriptive laboratory analyses and visits aiming to implement scheduled and prescribed treatment operations. such as inoculations. Physical therapy and so on. OECD Country input is not uniform either. France takes solely the visits for curative care into consideration. yet no further prolonged. rehabilitative or psychiatric care. In Germany. even when the patient visits his doctor more often. one treatment case merely makes the first contact in three months. The figures of Greece illustrate the average number of visits to doctors working in or contracted with the Social Insurance Institute. However. they exclude visits taken by private practitioners covered straight by a budget of a household. In Iceland visits to certain units for diagnostic purposes are excluded. In Israel house calls are included as well. Nederland does not include contacts for maternal and child health care. While Norway includes home care services. Poland reports visits provided by doctors conducting only publicly funded medical practices. Figures of United Kingdom leave out visits of the independent sector doctors and do not bear in mind specialist 
consultations apart from hospital outpatient clinics. Figures of United States excludes hospital-based physician visits. visits to specialists working in fields such as anesthesiology. pathology. and radiology. and visits to physicians who are chiefly committed to teaching. research. or administration. ${ }^{6}$ Trying to understand the position of our country compared to other countries shown on the same graph is somewhat trying to find a path through a mess of data pollution.

OECD definition document addresses to doctors' consultations (in all settings). and defines the variable as average number of consultations/visits with a physician per head per annum. ${ }^{6}$ Thus. one of the critical points seems to be "all settings". and the other "visit with a physician". The description of the figures of different countries show that settings are not "all". We are in doubt that the nature of all visits conducted with physicians are not the same either.

Almost all registered visits are conducted by physicians in Turkey. On the contrary. based on input from patient register of Norway. it is predicted that merely 57 percent of the hospitals consultations are conducted by physicians. ${ }^{6}$ In the USA. under certain circumstances. Medicare permits a nonphysician practitioner to perform some specific roles described in Medicare Benefit Policy Manual. ${ }^{7}$ Reports indicate that. midlevel practitioners are gaining acceptance all over the country. They are able to examine patients. order diagnostic tests. and prescribe certain types of medications. ${ }^{8}$ Non-physician visits are not included in the statistical data of doctor's visit.

Is it possible to make a comparison between a country where mid-level practitioners have widely acceptance and a country where only physicians are allowed to carry all patient practices. Different models of practices mentioned above show that sole numerical data under single definition is not enough to compare people's consultation to doctors.

It is known that factors including wealth status of today's societies. cultural differences. general attitude of health systems. demographic changes. operating and financing structure of health institutions. health insurance scheme. public policies and technology-based lifestyle all have certain amount of effects on the demand of health services. Based on this fact. no matter what measurement tools we have used. there is an increasing number of visits to doctors. ${ }^{9}$ On the other hand. as seen in our study. the meeting with the doctor is not always a doctor's visit in medical sense. In our case. less than half of the adult patients were first time admissions to health services in the hospital. New patients carry specific importance since they require. detailed anamnesis for patient records. They receive comprehensive examination. Defining different standards and fees for first patient visits can be seen in some health insurance models. Promoting such a policy might not bring extraordinary load to the system as it was seen that only $43.9(\%)$ of the patients were recorded as new.

The rate of established patients was 19.9 (\%) in total. Established patient visits to adult medicine specialties was significantly higher [27.4 (\%)]. With the help of a reasonable reorganization. doctors' workload can be decreased. shifting it to other professionals. Non-physician practitioners such as physician assistants or advanced practice nurses can share the workload at least in the follow-up of the patients. Established patients in medicine departments can be directed to hospitalists or family physicians rather than the same specialists.

A limited number of patients have been led around among disciplines for consultation or transfer of care. Some might be due to the need for real consultation. that is to say. the opinion or advise of a physician from different specialty regarding a specific problem was needed. However. referring some other patients to other physicians from different specialties to take over the responsibility for managing the patients' care or follow-up resulted due to different causes. Admissions directly to outpatient department of the hospital without visiting a primary health care physician sometimes results in not being able to select the right specialty for the patient 
him/herself. Similar cases would be expected more in a healthcare system without a proper referral chain. We believe that the reason of having a rate less than expected might be due to the fact that most of the specialist physicians act like general practitioners in their daily practice. ${ }^{10}$

It is observed that $4.1(\%)$ of patients admitted just to ask for prescription. for a complaint or addressing to a certain drug. without need for examination. Patients asking for represcribing the drugs that were written or used before were also included. The rationale for prescribing without medical examination and just based on patients' demand can be questioned on the side of its properness. as well as its burden on the specialist while many patients are waiting to be examined in the queue. A well-planned organization and team work can take this workload from specialists.

Pre-hospitalization visit rate in surgery [14.4 (\%)] was significantly higher. probably due to pre-operative testing or last control before hospitalizing for surgical intervention. It can be understood that most of these patients underwent Original Article investigations in the outpatient department. However. it is not easy to rationalize the male dominance in the pre-hospitalization group. Carrying out these services in the wards immediately after hospitalization instead of outpatient departments might also help to decrease the intensity of the crowds in these departments.

Physicians are authorized to prepare reports to document the condition of the patients for various reasons such as military service. marriage. disability opportunities. sports and travel. $3.3(\%)$ of the patients' aim who applied to the outpatient department was not to receive health service but to receive a health status report requested by other institutions for a variety of reasons. The rate was significantly high in medicine [5.1(\%)]. Doctor's visit for just reporting does not imply an actual physician-patient contact. Number of males in this category were significantly higher. Since men are more active in daily life. dealing with bureaucratic or business issues. their preference can be reasonable.

\section{CONCLUSION AND RECOMMENDATIONS}

The study indicates that. not all patientdoctor contacts were actual doctor's visit. in medical terms. Some of the contacts can easily be handled by non-physician practitioners. and some can be eliminated by just improving the process. The study being done within one hospital can be regarded as the major limitation of the study. Although the sample of the study is very limited. compared to the whole population of Turkey. our observations imply that there is not much difference in the other parts of the country. which needs to be proved by further studies. Detailed studies comprising different hospitals dispersed in line with NUTS 21(Nomenclature of Territorial Units for Statistics) are recommended for future research. Variables such as social and economic status of patients. health literacy of patients. relevant department. type of hospital should also be taken into consideration.

However. even these findings imply that the per capita doctor' visits in the country data need to be clarified. Rearrangement in the contact line and defining new professional roles can easily decrease the workload of physicians. Undoubtedly. more efficient use of qualified human resources will result with more qualifies service delivery. 


\section{REFERENCES}

1. OECD. (2018). "Healthcare Utilization OECD Health Statistics" Erişim adresi: https://doi.org/10.1787/data-00542-en (Erişim Tarihi 01.12.2019).

2. Health at a Glance 2013: OECD Indicators (2013). OECD Publishing.

3. Health Statistics Yearbook 2017. (2018). Ministry of Health (General Directorate of Health Information Systems. Ministry of Health), Ankara.

4 OECD. (2018). "OECD Health Statistics". Erișim adresi: http://www.oecd.org/health/health-data.htm (Erişim Tarihi 20.12.2019).

5. Toros. A. and Öztek. Z. (1993). Health Services Utilization in Turkey. 1992 National Survey Final Report. Republic of Turkey Ministry of Health, Ankara.

6. OECD. (2018). "OECD Health Statistics 2018 Definitions Sources and Methods". OECD Publishing. Erişim adresi: http://www.oecd.org/health/health-data.htm (Erișim Tarihi 20.12.2019)
7. Department of Health and Human Services. (DHHS). (2019) "Medicare Claims Processing Manual". Erişim adresi: https://www.cms.gov/Regulations-and-Guidance/Guidance/ Manuals/downloads/clm104c26.pdf (Erişim Tarihi 27.12.2019).

8. Blesi, M. (2017). Health care roles and responsibilities. In Medical Assisting. Administrative and Clinical Competencies. Cengage Learning.

9. Aydın, S. (2015). "Hekime Başvuru Sayısının Artış Hikâyesi". Sağlık Düşüncesi ve Tıp Kültürü Dergisi, 3, 6-13.

10. Özen, O. and Aydın, S. (2019). "The Historical Background of Transition from Socialization in Health Policy to Family Medicine Practices: Organizational Network of Primary Care in Turkey." J. Heal. Syst. Policies, 1, 79-86 